\title{
Information and Communication Technology in Public Sector Management in Kenya: Huduma Programme from The Perspective of Person with Disabilities
}

\author{
Charles M. Omboto ${ }^{1}$, Lydia W. Chege ${ }^{2}$ \\ \{ombotoc@kise.ac.ke1, chegel@kise.ac.ke²\} \\ Kenya Institute of Special Education, Nairobi, Kenya, Kenya Institute of Special Education, Nairobi, \\ Kenya
}

\begin{abstract}
According to World Health Organization (WHO,2011) 15 per cent of the world population consists of Persons Living with Disabilities (PLWDs) of which 80\% live in developing countries. Kenya National Bureau of Statistics survey 2009 (KNBS) show that an estimated 1.3 million Kenyans live with vision, hearing, mobility, cognitive disabilities or some form of disability (KNBS,2009). In 2013, the Kenya government initiated Huduma centre programme which is a single point of access to public services. This centres leverage on electronic services and information offered by different public agencies countrywide. This is the government initiative to access public service with ease through technology to her citizens. Therefore, the government Huduma programme will go a long way in providing a very good platform to achieve access, equity, and quality services especially Persons with disabilities. However, the concerns are whether PWD are accessing e-government services or not at these centres. With increasing recognition of rights for disadvantaged and vulnerable groups such as PWDS in Kenya, there is need for government to ensure that the e- services are accessible to all. This paper, therefore, seeks to establish the extent to which PWD access e-government services offered at these centres, highlighting issues PWDs face in accessing the services, drawing lessons. The paper further suggests the way forward in access to quality services for PWDs.
\end{abstract}

Keywords: E-government, Accessibility ICT, Persons Living with Disability, Huduma centres.

\section{Introduction}

According to WHO and World Bank (2011) More than a billion people live with some form of disability and $80 \%$ of them live in developing countries. Disability is both a cause and a consequence of poverty: poor people are more likely to become disabled, and people with disabilities (PWDs) are among the poorest and most vulnerable populations in the world. Individuals may experience different types of disability, including visual, hearing, speech, mobility, cognitive, and psychosocial disabilities, and others may also experience the onset of disability as they age. (World Bank, 2016).Kenya National Bureau of Statistics survey 2009 (KNBS) show that an estimated 1.3 million Kenyans live with vision, hearing, mobility, cognitive disabilities or some form of disability (KNBS,2009).

In 2008, the Convention on the Rights of Persons with Disabilities (CRPWD) took effect. This Convention is a commitment of the international community to include the perspective of disabilities and persons with disabilities in all aspects of development. This was strengthened 
by the UN General Assembly which attempted to discuss disability issues related to inclusion and integration of the rights, welfare and perspectives of persons with disabilities in the efforts of the Sustainable Development Goals (SDGs) at the national, regional and international levels.

Some organization such as Broadband Commission for Digital Development, Global Initiative for Inclusive Information and Communication Technology (G3ICT), the International Disability Alliance (IDA), International Telecommunication Union (ITU), Microsoft, Telecentre.org Foundation and the United Nations Educational, Scientific and Cultural Organization (UNESCO) have a document known as ICT Opportunities for a Framework for Inclusive Development for Disabilities.

The government plays a key role in the introduction of ICT-based solutions tailored to the needs of persons with disabilities (PWD), increasing the availability and accessibility of ICT; and promoting the affordability of assistive technology in all settings. This can be achieved through the promotion of e-government systems, as well as encouraging public-private collaboration, as well as the development and dissemination of knowledge, accessible products and content, and supporting technology (UNESCO, 2011).

ICTs for a Disability Inclusive Development Framework contribute to accelerating the social and economic inclusion of persons with disabilities. The availability of access and easy reach of ICT enables persons with disabilities to access education, skills training and employment, as well as opportunities to participate in the economic, cultural and social life of the community. Supporting facilities for the application of ICT is concrete action for stakeholders including the national government, the private sector, and civil and international organizations. This is in line with UNESCO's vision of inclusive development.

The Kenya government in 2013, initiated Huduma programme which is a single point of access to public services including electronic services and information offered by different public agencies countrywide. The government believes that everyone should have access to public service with ease through technology. Therefore, the government Huduma programme will go a long way in providing the best platform to achieve access, equity, and quality services Persons with disabilities. However, the concerns are whether PWD are accessing egovernment services or not at these centres. With increasing recognition for the rights for disadvantaged groups such as PWDS in Kenya, there is need for governments to ensure that egovernment services are accessible to all. In light of the above, this paper seeks to establish the extent to which PWD access e-government services offered at these centres, highlighting issues PWDs face in accessing the services, drawing lessons. The paper further suggests the way forward in access to quality services for PWDs.

\section{Extent to Which PWD Access E-Government Services Offered at Huduma Centres}

Improving E-governance services through the transition of government services, records, and documents to digital format can promote an independent and autonomous interface with government services and offices, greatly assisting persons with disabilities. In addition, government websites, social media, and crowdsourcing platforms are important sources of information for persons with disabilities (Bricout and Baker 2012; Infocomm Development Authority of Singapore 2013; Suomi and Krebs 2012). The application of digital services to government services (SMS, mobile applications, accessible web-based forms, and web portals 
and others) can meet the needs of persons with disabilities and facilitate interaction between the government and persons with disabilities. ICT referred to here are all information and communication devices or applications and their contents.

A report by Sumbwanyambe, Nel \& Clarke (2011) shows that most developing and developed countries are adopting universal service policies commonly known as One Stop Shop/ Citizens' Service Centres Models to reduce the digital divide among the country's information "haves" and "have-nots". Similarly, Abdalla (2016) report that the concept of citizen service centres is meant to facilitate clients to access information, service and transactions in one location. Countries continue to take different approaches to delivering online services such as self-service through internet or a hybrid of automated and manual processes at designated public accessible points.

In Kenya, the Huduma centres bring together various government services from different government bodies under one roof and an adoption of a mixed model with some services already automated while others are manual. Abdalla et al. (2016) note that the establishment of the centres was geared towards enhancing public service delivery to the citizens and businesses. Statistics from Huduma Kenya website show that these centers have become popular with Kenyans with approximately 15,500 Kenyans accessing services through the various centres across the country by 2013. This number has gone up by five time by this year 2019. Despite the perceived progress in Huduma Kenya Programme, the success of such initiatives depends on how citizens accept these services. As AlAwadhi \& Morris (2009) postulate government decision makers need an understanding of the factors that would encourage use of ICT rather than the old common delivery methods.

According to Jaeger \& Matteson (2009) for ICTs to be considered accessible they should be allowing access to all users and be compatible with assistive devices and technologies that PWD may use. Therefore, it should meet accessibility standards for ICT products and services that measure accessibility through a checklist attributes such as the Web Content Accessibility Guidelines (WCAG 2.0). However, for most ICT products or services, there is still no set of internationally agreed standards although there are several attempts by various stakeholders to implement them.

The ICT opportunity for persons with disabilities can be better assessed by analysing how each type of technology contribute to the different dimensions involved in the social and economic inclusion of persons with disabilities.

\section{Issues PWDs Face in Accessing Government Services}

Based on the latest 2013 G3ict CRPD ICT Accessibility Progress Report, it found that the majority of 76 participating countries do not have accessible government websites (55 percent), accessible public electronic kiosks, or country-based ATMs (61 percent), or programs available to facilitate the use of telephones by persons with disabilities (74 percent) (G3ict \& Disabled Peoples' International 2013). The study assessed the adoption rate of the ICT accessibility provisions in the CRPD to be 50 percent for certain ICT products and services, 47 percent for accessible features for computers, and 37 percent for accessible telecommunication and media services. The application of ICT has entered into the fabric of society and plays an important role for social progress and inclusive economic growth. Although there has been significant advancement in the ICT, PWD continue to face challenges 
in accessing e-government services in all if not most of all the huduma centres. These challenges include but not limited to:

1) Absence of assistive technology including training of staff on how to use them inaccessible IT products and services

2) Lack of appropriate devices or assistive technology, skills and design of system affect the general usage of e-government services by citizens but especially for citizens with disabilities

3) Inadequate policies governing use accessible ICTs and absence of proper implementation strategies.

4) Stakeholder awareness, knowledge, and capacity. In low and middle income countries, many persons with disabilities or their families and disability service providers, do not yet know the reach of ICT available and its use (Samant, Matter, and Harniss 2012).

5) Persons with disabilities lack awareness of what ICTs can do to facilitate their socioeconomic inclusion

6) There is very little documentation on participation by PWD in the design and development of E-government systems

7) The Huduma portal/website/systems have not been designed as per the required guidelines and standards for use by PWD

8) The current E-government services do not consider or address attributes of PWD.

\section{Lessons Learnt}

In 2008, the Government of Kenya has ratified the United Nations Convention on the Rights of Persons with Disabilities (CRPD). After the promulgation of the new Constitution in 2010, the Government is committed to ensuring and prioritizing fundamental freedoms and human rights without discrimination for persons with disabilities. If it is in accordance with the environment, according to WHO (2011), technology can increase participation and independence for persons with disabilities. They will become more communicative, mobile, and participate more in learning activities. This will have an impact on the self-image and selfesteem of persons with disabilities and will improve their quality of life.

Further, Assistive technology reduces costs for PWDs by supporting independent functioning and access to healthcare in lieu of personal support services, and independent community living in lieu of institutionalization.

Educated persons with a disability supported by assistive technology will have better opportunities in accessing employment (whether self- employment or waged) and reduces the link between disability and poverty.

Therefore, ICT4IE should be part and parcel of any government agenda and development strategy and a major concern for especially Kenya Government in its aspiration of delivering services to its public as well as promoting the disability welfare.

Internet and ICT can facilitate participation of PWDs in social, economic, and civic life. The use of multiple ICT channels to deliver services. The multiple formats for the content delivered can allow persons with different disabilities to access information and communication in the manner in which they prefer, comprehend and hence act. 


\section{Way Forward in Access to Quality Services for PWDs}

There is a need to build stakeholder capacity on how ICT may benefit persons with disabilities also on the large number of affordable and inexpensive accessibility solutions available. This also applies to many persons with disabilities, their families, and disability service providers, especially in low and middle income countries. The adoption and use of ace ssible ICT for inclusion is dependent on many actors in the ecosystem including government e-service providers, educators, employers, development practitioners, and the ICT industry in general.

However, both the international community and the Kenya government must address the existing barriers in order to fully leverage on the potential of ICT in the lives of persons with disabilities. This paper suggests the following recommendations that will assist in mainstreaming of disability in Kenya.

1. Improving legislation and policy.

2. Technical assistance and awareness creation.

3. Mainstreaming disability for inclusive development

4. ICT Authority, Huduma Kenya programme to work together to ensure accessibility to all e-government services provided at the centres through provision of devices and assistive technology

5. Strengthening research and development to facilitate growth of new ICT-enabled solutions for persons with disabilities as well as incorporating accessibility requirements in procurement policies

6. The government to give other forms of assistance, support services and facilities at the Huduma Centres to make it easy for PWD to access these services.

7. ICT Authority and other stakeholder to develop and implement ICT accessibility guidelines which can be adopted by other government departments and agencies. This will ensure that PWDs get the correct and timely services at these centres.

\section{References}

[1]. Abdalla, A. G., Kiragu, J. K., Waswa, F. A., Ono, F. T., Kariuki, J. W., \& Ikua, D. M. (June 2015). Effect of Huduma Centers (One Stop Shops) in Service Delivery - A Case Study of Mombasa Huduma Centre. International Journal of Academic Research in Business and Social Sciences, 102-117.

[2]. Almarabeh, T., \& AbuAli, A. (2010). A General Framework for E-Government: Definition Maturity Challenges, Opportunities, and Success. European Journal of Scientific Research, 29-42.

[3]. Alshawi, S., Alahmary, A., \& Alalwany, H. (2007). E-Government Evaluation Factors:Citizen's Perspective. Proceedings of European and Mediterranean Conference on Information Systems. Valencia: EMCIS.

[4]. Alshehri, M., \& Drew, S. (2010). Challenges of e-Government Services Adoption in Saudi Arabia from an eReady Citizen Perspective. World Academy of Science, Engineering and Technology $662010,10541059$.

[5]. ITU and G3ICT (2012) "Making Mobile Phones and Services Accessible for Persons with Disabilities" August 2012 
[6]. ITU. (2014). Measuring the Information Society Report 2014. Retrieved January 28, 2019, from ITU releases 2014 ICT figures: www.itu.int

[7]. ITU. (2014, November). Model ICT Accessibility Policy Report - ITU. Retrieved January 30, 2015, from The Model ICT Accessibility Policy: Digital Inclusion: www.itu.int/

[8]. Kenya National Bureau of Statistics. (2010). The 2009 Kenya Population and Housing Census. Kenya National Bureau of Statistics, Nairobi. Retrieved May 10, 2019, from www.knbs.or.ke

[9]. Maina, D.K (2016), Citizen Centric Evaluation of Accessibility of ICT Services for Persons With Disability: A Case Study of Huduma Centres In Kenya. Unpublished Master's thesis, University of Nairobi.

[10]. Murugami, M., \& Mazrui, L. (2012, May). Barriers to Internet Access for Persons with Disabilities. Retrieved from Kenya Disability Web Portal: http://www.kenyadisability.or.ke/

[11]. Sumbwanyambe, M., Nel, A., \& Clarke, W. (2011). Challenges and Proposed Solutions Towards Telecentre Sustainability: A Southern Africa Case Study. IST-Africa 2011 Conference Proceedings. Dublin: IIMC International Information Management Corporation,.

[12]. Wafula , J. M. (2007). ICT Policy and Strategies: Towards E-Governance and Sustainable Development-The Case of East African Community and Kenya (Doctoral Thesis). Retrieved from http://ir.jkuat.ac.ke/

[13].World Health Organisation \& World Bank. (2011). World Report on Disability 2011. Malta: WHO. 